\title{
A comparison of lower montane natural forest (Abies, Fagus, Picea) in Oszast Reserve and spruce monocultures in the Żywiecki Beskid and Śląski Beskid
}

\author{
Andrzej Jaworski, Maciej Pach* \\ University of Agriculture in Kraków, Faculty of Forestry, Department of Silviculture, \\ A1. 29 Listopada 46, 31-425 Kraków, Poland. \\ *Tel. +48 012 6625371, e-mail: rlpach@cyf-kr.edu.pl
}

\begin{abstract}
The aim of this research was to find out what changes occurred between 1999-2009 in Oszast reserve in the volume, species composition and diameter at breast height (dbh) distribution of the forest stand, and the number and height of regeneration. The objective was to determine what would be condition of these managed lower montane multispecies forest stands (Swiss irregular shelterwood method or selection cuttings) and what role spruce would play in them if they have not been replaced by spruce monocultures.

The research was conducted on three permanent circular sample plots (s.p.), each had size of 1/3 ha.

Over 10 years, standing volume of the forest stand increased on s.p. 1 (from around $562 \mathrm{~m}^{3} / \mathrm{ha}$ to $649 \mathrm{~m} / \mathrm{ha}$ ) and s.p. 3. (from $653 \mathrm{~m}^{3} / \mathrm{ha}$ to $660 \mathrm{~m}^{3} / \mathrm{ha}$ ), while decreased on s.p. 2. (from $421 \mathrm{~m}^{3} / \mathrm{ha}$ to $378 \mathrm{~m}^{3} / \mathrm{ha}$ ). The species composition, defined on the basis of volume share (averaged for the three s.p. jointly), did not undergo consistent changes. However, the relative dominance of beech over spruce was determined based on tree numbers.

The average spruce mortality (averaged from three s.p.) did not exceed 10\% and was slightly higher than that of beech $(6 \%)$, and lower than fir mortality (15\%). Nevertheless, spruce did not show any symptoms of dieback. The reasons behind its mortality were fallen trees and windbreaks. In regeneration, on the whole, beech or sycamore predominated, and the proportion of spruce and fir was small. In the future spruce and fir may even decrease further by competitive ability of dynamically regenerating beech.

Abandonment of forest management to promote greater diversity of species, may favour the formation of beech monocultures, or forest stands dominated by beech, everywhere that beech is already present or will be introduced.

The maintenance of stable, multispecies forest stands, with co-dominant fir, beech and spruce of native origin, requires natural or artificial regeneration of spruce and fir, manipulated to restore fir up to about $30 \%$, and reduce spruce down to about $40 \%$. This would be possible through the use of the Swiss irregular shelterwood method and selection system, and by continuous tending of regeneration.
\end{abstract}

Key words: stand volume, dbh distribution, mortality, regeneration

\section{Introduction}

Scientists and forestry practitioners repeatedly stated, that forest management may profit from better understanding of the dynamics of primeval forest. Interest in primeval forests was often motivated by the argument that they were free from human activity, and studying these forests was an opportunity for deepening the knowledge of structure and forest dynamics (Leibundgut 1959). Such knowledge seems to be particularly valuable when taken into consideration is current trend, leading to closeto-nature silviculture (Otto 1995; Schütz 1999, 2004). 
A new attempt of primeval and natural forest comparison for silviculture benefit is establishing couples of sample plots (s.p.) in forest reserves and in nearby managed forests (Meyer et al. 2004). If plots in pairs present similar habitat conditions and similar development stage, and if the forest stand's history is similar, then they can be compared directly. Subsequently, the management influence on forest stand features (structure, productivity, vitality) and environment features can be defined quantitatively.

The comparison of natural forests with managed forests of artificial origin with species composition inconsistent with habitat conditions is also possible, which are for example spruce monocultures. This is the case with the forest stands on the area of Beskid Żywiecki and Śląski Mts. In the period 1860-1880, thousands of hectares of spruce monocultures were formed at the expense of lower montane forest zone primeval forest, composed of spruce, beech and fir (Kawecki 1939). In 1893, first age class spruce monocultures located in forest stands of Beskid Żywiecki encompassed a surface of 10.000 ha and fifth age class mixed stands 14.239 ha (Kawecki 1939). Introducing spruce on a massive scale in lower montane forest zone forests was incompatible with the principal of tree species selection for particular habitat, proclaimed by Pfeil as early as in 1860 (Schütz 1990). Human aspiration to increase yields regardless of consequence induced and still is inducing strong 'ecological retaliation' (Odum 1977). Observed in Beskid Żywiecki and Śląski Mts, forests mass spruce dieback, initiated in 2006, is a convincing example of this process (Barszcz et al. 2009; Szabla 2009; Bruchwald and Dmyterko 2010). Such catastrophic large-area dieback was not started in lower montane forest zone natural forest stands composed of beech, fir and spruce in Śrubita and Oszast reserves, situated among spruce monocultures in Beskid Żywiecki Mts.

Relatively good state of lower montane forest zone forests in the Oszast reserve, showing virgin character, has become a premise for conducting research on three permanent circular experimental plots in 1999. The first results were published after two years (Jaworski et al. 2001). In 2009, control measurements were performed.

The aim of the research was to find out what changes occurred in the years 1999-2009 in Oszast reserve in terms of stand volume, species composition and forest stand's structure. In this paper, an answer to the following question is attempted: what was the cause of tree loss in the reserve?
The measurement conducted in 2009 took place during catastrophic disintegration of spruce monocultures in Beskid Żywiecki and Śląski Mts, which is mentioned above.

In this paper, the following hypotheses are made:

- In the Oszast reserve, in multispecies forests, spruce does not show any symptoms of dieback due to biotic reasons.

- In the lower montane forest zone forest stand, beech will be a dominant species.

- Lower montane forest zone multispecies stands may play the role of a model forest in terms of species composition and structure in the case of spruce monocultures conversion of Beskid Żywiecki and Śląski Mts.

\section{Material and methods}

\section{Location and reserve's habitat characteristics and research plot}

The Oszast reserve (surface $47.31 \mathrm{ha}$ ) is located in the peak-part of Oszast hill (1147 m above sea level (a.s.1.)), which is a southern part of Beskid Żywiecki Mts. (Raczańska part) that adjoins the border with Slovakia. The name Oszast (Uszust) is probably derived from the local dialect definition of difficult terrain conditions. The reserve with partial protection, created in 1971, includes fragments of former, lower montane forest zone of Karpaty's primeval forest. Partial protection covered surface of 47.31 ha in the compartments 200 and 201 of Cichy Forest Range, Ujsoły Forest District. From 2008, it is a strict reserve. The reserve is located on a steep slope, in some places even precipitous, with several terraces (flattening) with $\mathrm{N}-\mathrm{W}$ aspect, in a height of $950-1147 \mathrm{~m}$ a.s.l. in cold climate zone (average year temperature estimates from $+2^{\circ} \mathrm{C}$ to $+4^{\circ} \mathrm{C}$ ) with precipitation around 1300 $\mathrm{mm}$ (Hess 1965).

In reserve, association Dentario glandulosae-Fagetum dominates, and other associations and communities, Aceri-Fagetum, Abieti-Piceetum montanum and Sorbo-Aceretum carpaticum, occupy a small area.

Three circular samples plots of size $1 / 3$ ha were located in compartment 201a, in the best saved forests, representing prevailing stages and phases of development, which were chosen on the basis of structure features and other criteria described by Korpel (1989). Habitat-forest stand's characteristics of examined s.p. were given in Table 1. 
Table 1. Location of study plots, their site and stand characteristics

\begin{tabular}{|c|c|c|c|}
\hline Sample plot & Oszast 1 (p.p. 1) & Oszast 2 (p.p. 2) & Oszast 3 (p.p. 3) \\
\hline Location & \multicolumn{3}{|c|}{$201 \mathrm{a}$} \\
\hline \multirow{2}{*}{ Geographic coordinates } & $49^{\circ} 24^{\prime} 41,22^{\prime \prime} \mathrm{N}$ & $49^{\circ} 24^{\prime} 42,6^{\prime \prime} \mathrm{N}$ & $49^{\circ} 24^{\prime} 43,2^{\prime \prime} \mathrm{N}$ \\
\hline & $19^{\circ} 11 ’ 9,8 ’ \mathrm{E}$ & $19^{\circ} 11 ’ 7,6 ” \mathrm{E}$ & $19^{\circ} 11 ’ 20,0 ’ \mathrm{E}$ \\
\hline Size [ha] & $1 / 3$ & $1 / 3$ & $1 / 3$ \\
\hline Aspect & N-NW & $\mathrm{N}$ & N-NW \\
\hline Slope $\left[{ }^{\circ}\right]$ & 26 & 26 & 18 \\
\hline Altitude a.s.1. [m] & 1030 & 990 & 1000 \\
\hline Soil & \multicolumn{3}{|c|}{ Endoeutric Cambisol } \\
\hline Plant association & \multicolumn{3}{|c|}{ Dentario glandulosae-Fagetum } \\
\hline Age [years] & \multicolumn{3}{|c|}{ Abies alba 120-220; Fagus sylvatica 65-90-120-200; Picea abies 170-220 } \\
\hline $\begin{array}{c}\text { Stage and phase } \\
\text { of development } \\
\text { in } 2009\end{array}$ & $\begin{array}{c}\text { growing up stage, } \\
\text { the phase of multi-layer } \\
\text { structure }\end{array}$ & $\begin{array}{l}\text { slowly break up stage, } \\
\text { the phase of multi-layer } \\
\text { structure }\end{array}$ & $\begin{array}{l}\text { the end of optimum growth stage, } \\
\text { long-lasting phase of ageing and } \\
\text { regeneration forming multi-layer stand }\end{array}$ \\
\hline
\end{tabular}

\section{Research methodology}

Field works were performed in August 1999 and were repeated in August 2009. They included diameter at breast height (dbh) measurement (with an accuracy up to $0.5 \mathrm{~cm}$; dbh measurement threshold was $6 \mathrm{~cm}$ ) and height measurement of all live trees (with the exception of strongly inclined trees) with Vertex hypsometer. Permanent trees numbering was used, with marking of the place of dbh measurement.

Trees of dbh $d_{1.3} \geq 8 \mathrm{~cm}$ were also included in Řehák (1964) classification (trees categories). The number of natural seedling (1-year-old seedling and natural seedling to $50 \mathrm{~cm}$ height) was defined on strips $10 \mathrm{~m}$ wide. Those strips of length equal to the circular plot's diameter run through its centre, perpendicular to the contour line.

The conducted measurements of trees dbh $d_{1.3} \geq 8 \mathrm{~cm}$ allowed for definition of dbh distribution type, according to Pearson's curves classification (Zieliński 1972) and calculation of dbh basal area and volume. To calculate the volume, program 'Resources' developed by J. Ptak was applied with the use of Czuraj (1991) standing trees volume tables. Trees of dbh $6.0-7.9 \mathrm{~cm}$ were included to overgrown (older) underwood.

In the paper, regeneration's species composition and also tree mortality $d_{1.3} \geq 8 \mathrm{~cm}$ in the years 1999-2009 were determined, expressed with dead specimen per- centage in relation to the tree number in the beginning of control period.

All tree species dbh distributions and beech's and spruce's dbh distribution in years 1999 and 2009 were compared with Kołmogorow-Smirnow test.

\section{Results}

\section{Number of trees and volume, basal area and forest stand's species composition}

During the research period (1999-2009) on all three plots, the number of trees increased: on s.p. 1 by $16.7 \%$ (number of trees in $1999=100 \%$ ), on s.p. 3 by $12.1 \%$ and on s.p. 2 by $6.2 \%$. On all plots beech's share increased, and percentage of other trees species decreased (Table 2).

On s.p. 1, volume increased visibly (by $86.5 \mathrm{~m}^{3} / \mathrm{ha}$ ), on s.p 3 slightly (by $6.5 \mathrm{~m}^{3} / \mathrm{ha}$ ), whereas on s.p. 2 it decreased considerably (by $44 \mathrm{~m}^{3} / \mathrm{ha}$ ) (Table 2). Basal area decreased significantly on s.p. 1 (by slightly over $6 \mathrm{~m}^{2} /$ ha), slightly (by almost $1 \mathrm{~m}^{2} /$ ha) on s.p. 3 and decreased on s.p. 2 (by near $3 \mathrm{~m}^{2} / \mathrm{ha}$ ).

Species composition defined on the basis of volume share showed increase of spruce's share on s.p. 3, and also showed its significant drop on s.p. 2 and maintenance of the hitherto state on s.p. 1 (Table 2). Beech increased its share on s.p. 1 and 2, and decreased on s.p. 3. Fir's 
Table 2. Number of trees, stand volume, basal area and species composition of investigated stands in 1999 and 2009

\begin{tabular}{|c|c|c|c|c|c|c|c|c|c|c|c|c|}
\hline \multirow{3}{*}{ Species } & \multirow{2}{*}{\multicolumn{2}{|c|}{$\begin{array}{c}\begin{array}{c}\text { Number of } \\
\text { trees (trees/ha) }\end{array} \\
\mathrm{N}\end{array}$}} & \multirow{2}{*}{\multicolumn{2}{|c|}{$\begin{array}{c}\begin{array}{c}\text { Basal area } \\
\left(\mathrm{m}^{2} / \mathrm{ha}\right)\end{array} \\
\mathrm{G}\end{array}$}} & \multirow{2}{*}{\multicolumn{2}{|c|}{$\begin{array}{c}\begin{array}{c}\text { Volume } \\
\left(\mathrm{m}^{3} / \mathrm{ha}\right)\end{array} \\
\mathrm{V}\end{array}$}} & \multicolumn{6}{|c|}{$\begin{array}{c}\text { Species composition } \\
(\%)\end{array}$} \\
\hline & & & & & & & \multicolumn{2}{|c|}{$\mathrm{N}$} & \multicolumn{2}{|c|}{ G } & \multicolumn{2}{|c|}{$\mathrm{V}$} \\
\hline & 1999 & 2009 & 1999 & 2009 & 1999 & 2009 & 1999 & 2009 & 1999 & 2009 & 1999 & 2009 \\
\hline \multicolumn{13}{|c|}{ Oszast 1} \\
\hline Picea abies & 96 & 96 & 28.926 & 33.213 & 405.41 & 472.86 & 33.3 & 28.6 & 68.8 & 68.9 & 72.1 & 72.9 \\
\hline Fagus sylvatica & 150 & 204 & 6.605 & 8.941 & 63.44 & 88.53 & 52.1 & 60.7 & 15.7 & 18.5 & 11.3 & 13.6 \\
\hline Acer pseudoplatanus & 24 & 24 & 1.736 & 2.181 & 20.30 & 25.11 & 8.3 & 7.1 & 4.1 & 4.5 & 3.6 & 3.9 \\
\hline Abies alba & 18 & 12 & 4.782 & 3.890 & 72.99 & 62.11 & 6.3 & 3.6 & 11.4 & 8.1 & 13.0 & 9.6 \\
\hline Total & 288 & 336 & 42.050 & 48.225 & 562.15 & 648.61 & 100.0 & 100.0 & 100.0 & 100.0 & 100.0 & 100.0 \\
\hline \multicolumn{13}{|c|}{ Oszast 2} \\
\hline Picea abies & 87 & 72 & 21.217 & 16.361 & 292.25 & 223.23 & 22.3 & 17.4 & 61.7 & 51.5 & 69.4 & 59.1 \\
\hline Fagus sylvatica & 234 & 273 & 7.861 & 8.957 & 67.35 & 77.67 & 60.0 & 65.9 & 22.8 & 28.2 & 16.0 & 20.6 \\
\hline Acer pseudoplatanus & 51 & 54 & 3.120 & 3.893 & 34.26 & 44.28 & 13.1 & 13.1 & 9.1 & 12.2 & 8.1 & 11.7 \\
\hline Abies alba & 15 & 15 & 2.183 & 2.579 & 27.29 & 32.40 & 3.8 & 3.6 & 6.3 & 8.1 & 6.5 & 8.6 \\
\hline Sorbus aucuparia & 3 & - & 0.026 & - & 0.13 & - & 0.8 & - & 0.1 & - & - & - \\
\hline Total & 390 & 414 & 34.406 & 31.789 & 421.27 & 377.58 & 100.0 & 100.0 & 100.0 & 100.0 & 100.0 & 100.0 \\
\hline \multicolumn{13}{|c|}{ Oszast 3} \\
\hline Picea abies & 129 & 120 & 32.212 & 34.285 & 491.73 & 523.87 & 28.9 & 24.0 & 69.1 & 72.0 & 75.3 & 79.4 \\
\hline Fagus sylvatica & 312 & 375 & 13.784 & 12.484 & 151.36 & 122.94 & 69.8 & 74.8 & 29.5 & 26.2 & 23.2 & 18.6 \\
\hline Abies alba & 6 & 6 & 0.655 & 0.838 & 10.08 & 12.81 & 1.3 & 1.2 & 1.4 & 1.8 & 1.5 & 2.0 \\
\hline Total & 447 & 501 & 46.651 & 47.607 & 653.17 & 659.62 & 100.0 & 100.0 & 100.0 & 100.0 & 100.0 & 100.0 \\
\hline
\end{tabular}

share increased slightly on s.p. 2, decreased on s.p. 1, and maintained on the same level on s.p. 3 (Table 2).

Species composition defined on the basis of dbh basal area appeared analogically (Table 2).

\section{Type of dbh distribution}

During the 10-year-period, the type of dbh distribution of all trees species did not change (Fig. 1). It corresponded to the following types of curves by Pearson's classification: s.p. 1 - I (J) (type I unimodal with modal at the edge of range); s.p. 2 - did not correspond to any of types; and s.p. 3 - I (U) (type I bimodal).

Kołmogorow-Smirnow test showed that on examined plots, dbh distribution of all trees, beeches and spruces from 1999 and 2009 did not differ significantly.

\section{Mortality}

On s.p. 1, two firs died (of B3 category) (Table 3). Tree mortality of this species was 33\% (Table 4). On s.p. 2, the cause of beech loss (category B2, B3, C2, C3) and spruce's loss (category A2, B2, B3 and C1) was their overturn (trees fallen from wind) and windbreak (only one spruce died) (Table 3). Beech's and spruce's mortality on s.p. 2 was respectively almost $8 \%$ and slightly over $24 \%$ (Table 4 ). On s.p. 3, the greatest loss was among beeches (B2 and B3 category and C2 and C3), which happened as a result of wind-fallen and broken trees (Table 3). On this plot, spruce of category A2 died, and spruces of $\mathrm{C} 1$ and $\mathrm{C} 3$ category died as a result of windbreak (Table 3). Mortality was close to $8 \%$ for beech and $7 \%$ for spruce on this s.p. (Table 4 ). 

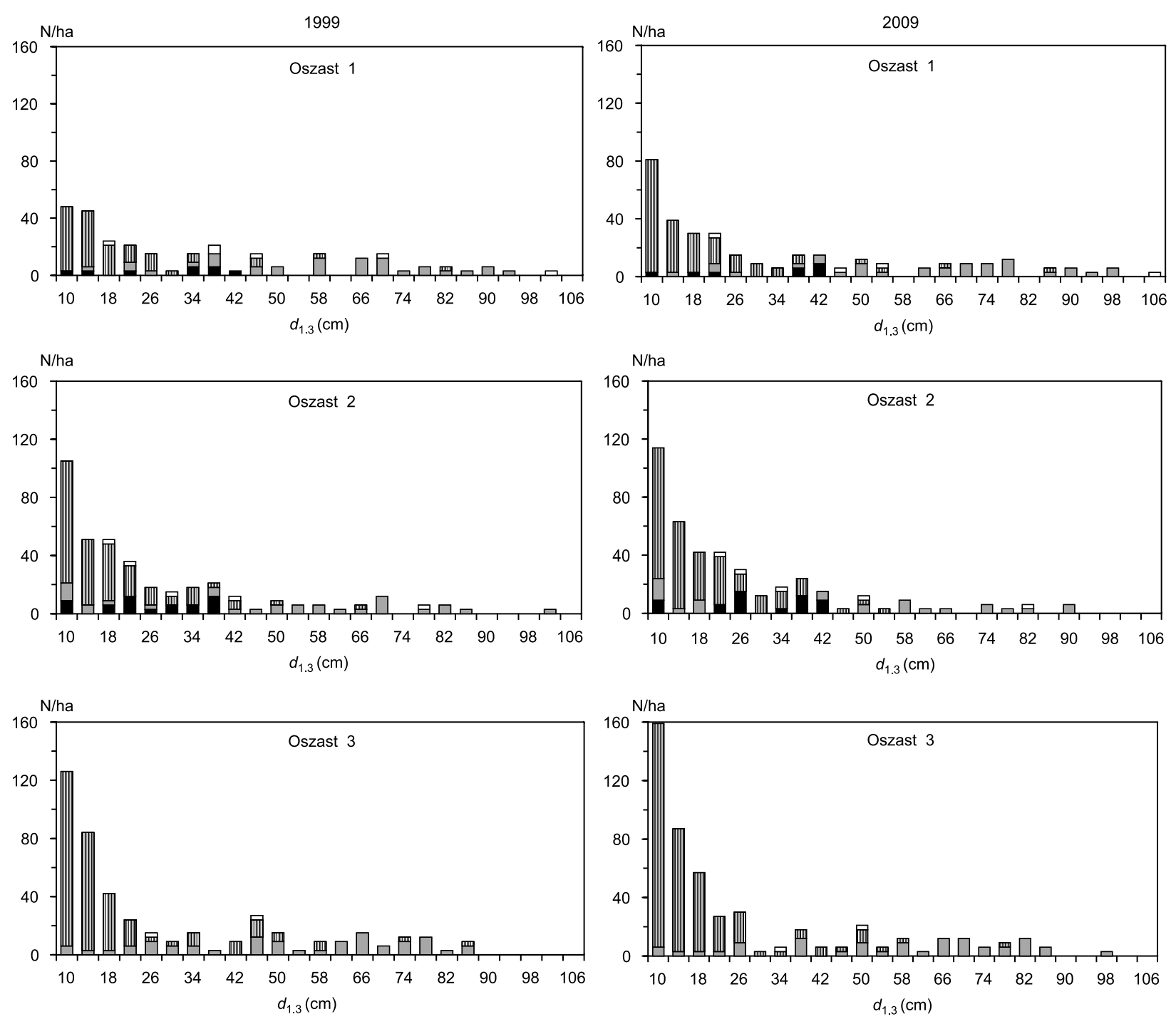

$\square$ Abies alba $\quad$ 血 Fagus sylvatica

Picea abies

inne / other

Figure 1. Dbh distribution in the investigated stands in 1999 and 2009

\section{Regeneration}

In 1999, the most seedlings (1-year-old) were sycamore maple's; slightly less in number were fir's and beech's seedlings, and spruce's seedlings did not occur at all. In 2009, seedlings were found occasionally: on s.p. 1 - fir's and sycamore maple's seedlings, and on s.p. 2 - fir's seedlings. On s.p 3, no seedlings were recorded (Table 5).

In 1999, on s.p. 1 and 3 among natural seedling (to height $50 \mathrm{~cm}$ ) beech's seedling dominated, and on s.p. 2 sycamore maple's. Spruce share in natural seedlings was from $9 \%$ on s.p. 3 to $21 \%$ on s.p. 1 , and fir's seedlings from around $2 \%$ on s.p. 1 and 2 to $7 \%$ on s.p. 3 (Table 5).

After 10 years, on s.p. 1 and 2 among natural seedlings sycamore maple dominated and on s.p 3 beech. Fir's share was from $1 \%$ on s.p. 1 to around $17 \%$ on s.p. 3. Spruce's share did not exceed $5 \%$ on any s.p. (Table 5).

On the beginning of control period, among underwood beech dominated on s.p. 2 and 3, and sycamore maple on s.p. 1. Fir's underwood was not present on s.p. 2, and on s.p. 1 and 3 share of this species in underwood was about $1 \%$. More often than fir, spruce occurred: from around $1 \%$ on s.p. 3 to $8.5 \%$ on s.p. 2 (Table 5). 
Table 3. The characteristics of trees belonging to losses on sample plots in 1999-2009

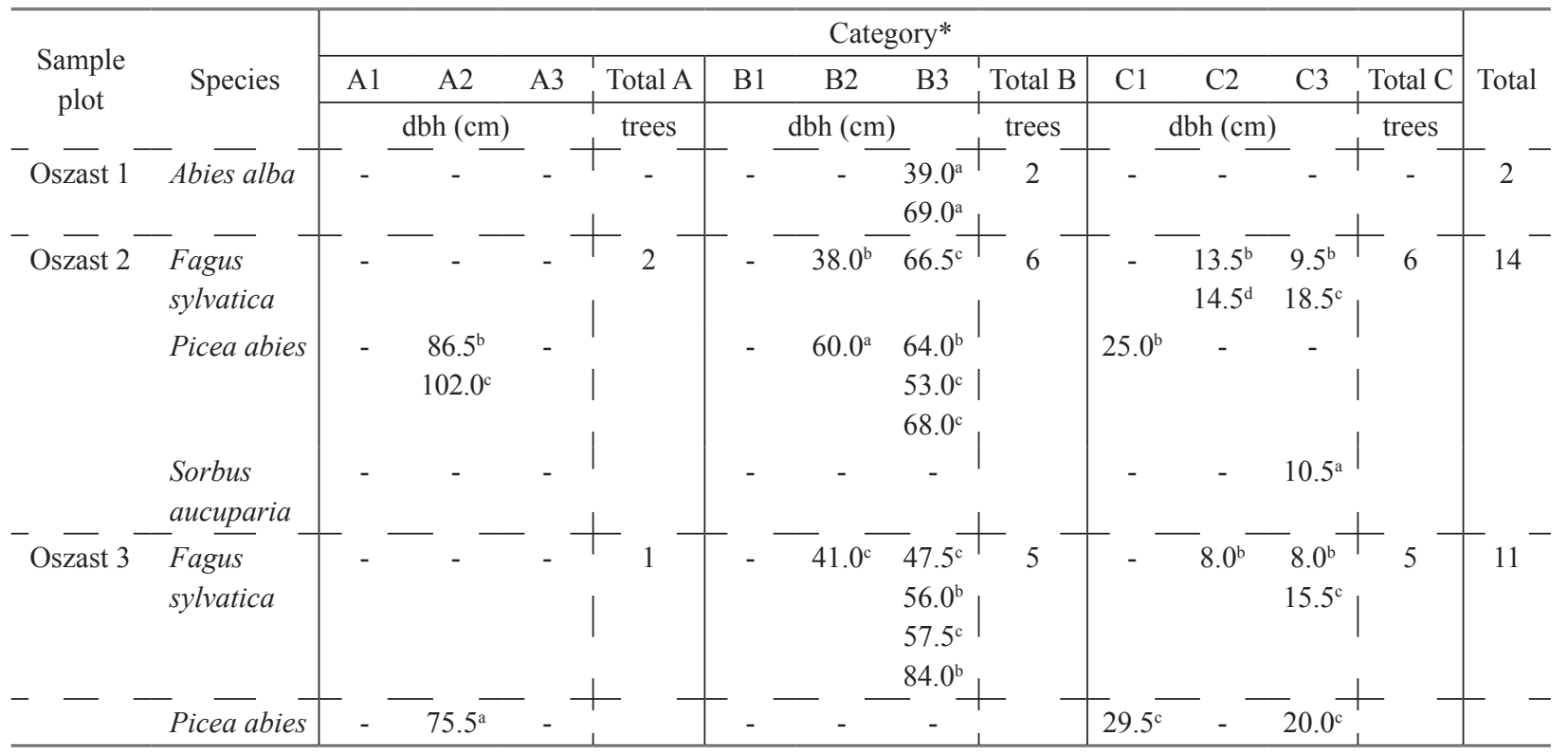

*Generation of trees: A - of old age, $\mathrm{B}$ - of optimum growth, $\mathrm{C}$ - of growing up

Vitality: 1 - the most vigorous tree, 2 - normal tree, 3 - weakened tree

Causes of losses: $\mathrm{a}$ - self-thinning or dying, $\mathrm{b}$ - windfall, $\mathrm{c}$ - broken, $\mathrm{d}$ - crushed

Table 4. The number of trees, recruitment, losses and mortality of trees on sample plots

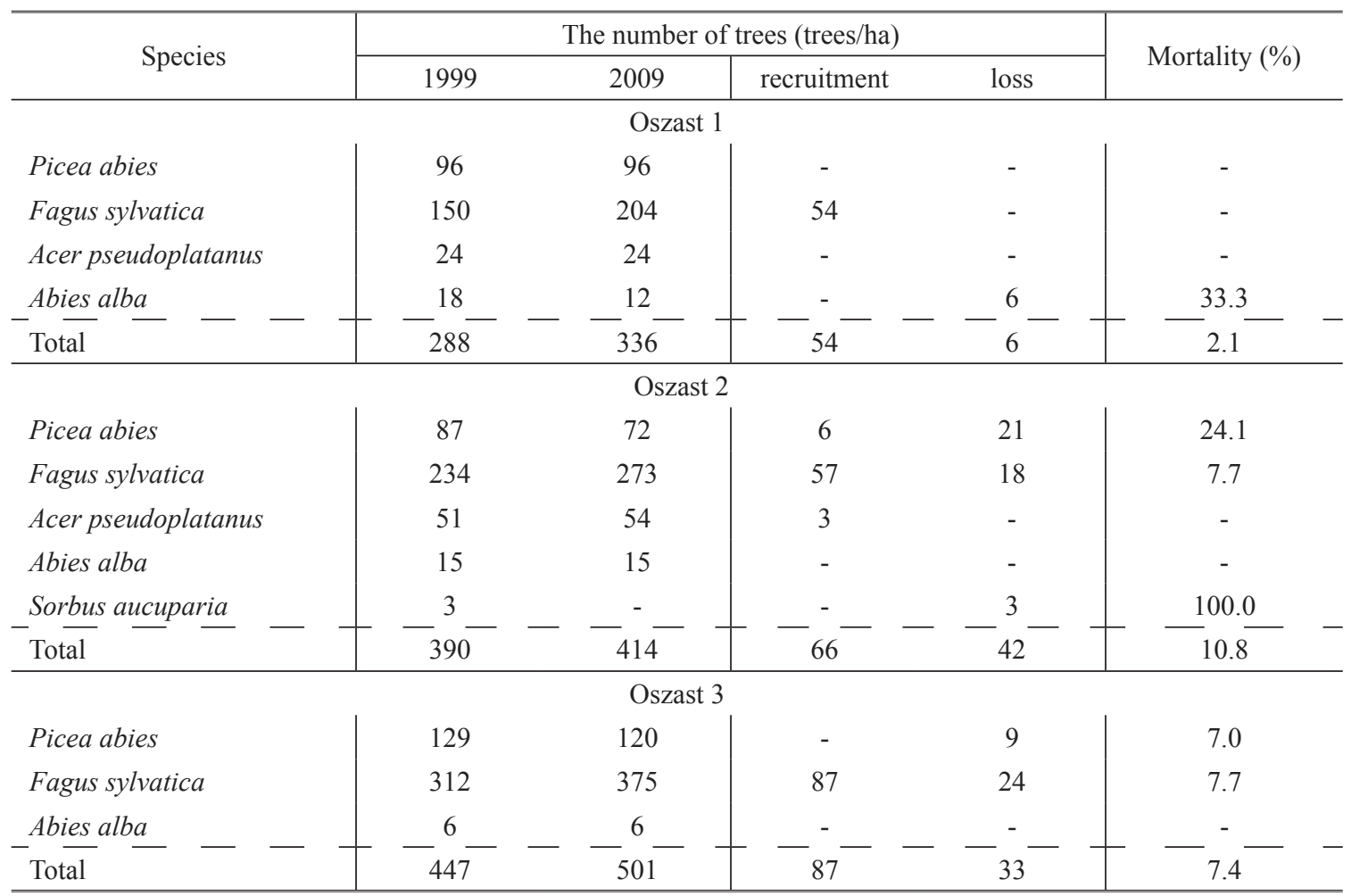

* Ratio of the tree number of tree loss to the number of living trees in a 1999 
Table 5. Numbers and percentage of regeneration on sample plots in 1999 and 2009

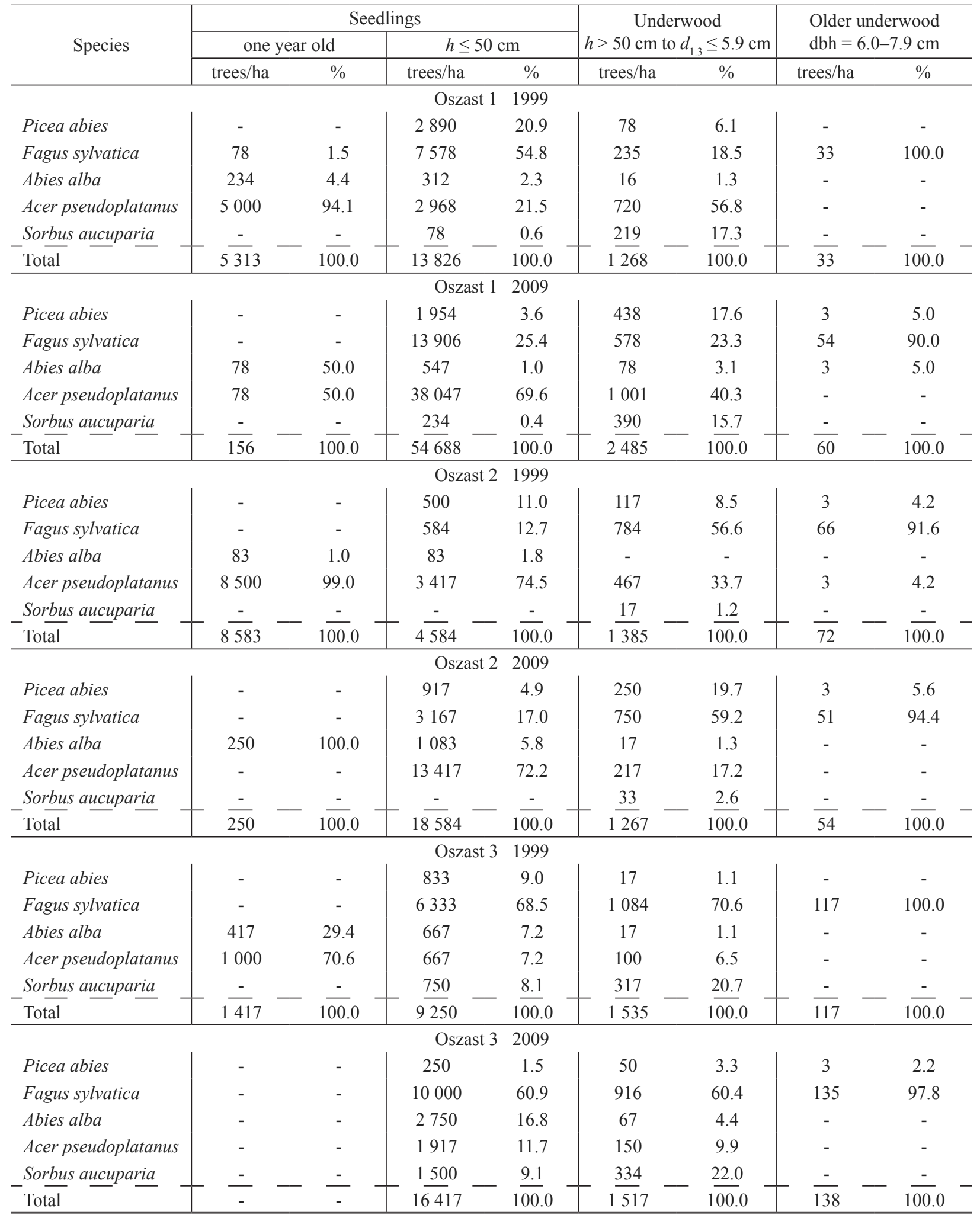


Table 6. Species composition of stand in 1999-2009 (mean value for three plots)

\begin{tabular}{|c|c|c|c|c|c|c|c|c|}
\hline \multirow{3}{*}{ Species } & \multicolumn{4}{|c|}{1999} & \multicolumn{4}{|c|}{2009} \\
\hline & \multicolumn{2}{|c|}{$\mathrm{N}$} & \multicolumn{2}{|c|}{ V } & \multicolumn{2}{|c|}{$\mathrm{N}$} & \multicolumn{2}{|c|}{ V } \\
\hline & trees/ha & $\%$ & $\mathrm{~m}^{3} / \mathrm{ha}$ & $\%$ & trees/ha & $\%$ & $\mathrm{~m}^{3} / \mathrm{ha}$ & $\%$ \\
\hline Picea abies & 104 & 27.7 & 396.46 & 72.67 & 96 & 23.0 & 406.65 & 72.36 \\
\hline Fagus sylvatica & 232 & 61.8 & 94.05 & 17.24 & 284 & 68.1 & 96.38 & 17.15 \\
\hline Abies alba & 13 & 3.5 & 36.79 & 6.75 & 11 & 2.7 & 35.77 & 6.37 \\
\hline Others & 26 & 7.0 & 18.23 & 3.34 & 26 & 6.2 & 23.13 & 4.12 \\
\hline Total & 375 & 100.0 & 545.53 & 100.00 & 417 & 100.0 & 561.93 & 100.00 \\
\hline
\end{tabular}

Table 7. Volume and species composition of stand in Oszast in 1949, 2009 and 2010

\begin{tabular}{|c|c|c|c|c|c|c|}
\hline \multirow{3}{*}{ Species } & \multicolumn{6}{|c|}{ Volume } \\
\hline & $\mathrm{m}^{3} / \mathrm{ha}$ & $\%$ & $\mathrm{~m}^{3} / \mathrm{ha}$ & $\%$ & $\mathrm{~m}^{3} / \mathrm{ha}$ & $\%$ \\
\hline & \multicolumn{2}{|c|}{ 1949* } & \multicolumn{2}{|c|}{$2010 * *$} & \multicolumn{2}{|c|}{$2009 * * *$} \\
\hline Picea abies & 625.27 & 48.4 & 329 & 76.7 & 406.5 & 73.1 \\
\hline Fagus sylvatica & 248.32 & 19.2 & 72 & 16.8 & 91.04 & 16.4 \\
\hline Abies alba & 393.43 & 30.4 & 28 & 6.5 & 35.77 & 6.4 \\
\hline Acer pseudoplatanus & 25.41 & 2.0 & singly & 0.0 & 23.01 & 4.1 \\
\hline Total & 1291.43 & 100.0 & 445 & 100.0 & 556.32 & 100.0 \\
\hline
\end{tabular}

Source:

1949* data of measurements of stands belonging to the Ujsoły Forest District (200d forest compartment)

$2010 * *$ data from the Management Plan of Oszast Reserve Protection (201a forest compartment)

$2009 * * *$ mean values from measurements done on three sample plots in 201a forest compartment (dbh $\geq 14 \mathrm{~cm})$

After 10 years, on s.p. 2 and 3 among underwood beech dominated, and on s.p. 1 sycamore maple. Spruce's share was from around 3\% (s.p. 3) to 20\% (s.p. 2). Fir's share did not exceed $5 \%$ (Table 5 ).

Overgrown underwood $\left(d_{13}=6-7.9 \mathrm{~cm}\right)$ occurred rarely. In 1999, the highest was beech's share (from $92 \%$ to $100 \%$ ) (Table 5). In 2009 among this tree class beech also dominated (Table 5).

\section{Discussion}

Diversity of volume changes - its increase and decrease - and diversity of species composition on examined plots (Table 2) in the Oszast reserve have mosaic character and are a feature of natural forests, which is confirmed by Korpel long-term studies $(1989,1995)$.

Average share of each of three trees species defined on the basis of volume from three examined plots did not change significantly during 10 years, where- as share determined on the basis of tree number increased in case of beech, decreased in case of spruce and slightly decreased in case of fir (Table 6). Increase of beech's share in 10-year-period is associated with greater number of those species recruitment than other species. A decrease of spruce's share is the result of its loss, few underwood, and in consequence a lack of recruitment (Tables 4 and 5). Maintaining of spruce's volume share in case of its number share decrease indicates large volume increment, and therefore good vitality of this species.

Permanent lack of spruce's regeneration (underwood) may cause decrease of this species share in the future because it has no favourable conditions for regeneration and development under dynamically developing beech's regeneration (Table 5).

Presently, Oszast reserve's forest stands differ significantly in terms of volume and species composition from the state before 60 years (Table 7). 
The management plan for period 1949-1958 indicates that one of the current reserve compartments (comp. 200c, currently 200d) of surface 19.95 ha was covered by dbh measurement (from $14 \mathrm{~cm}$ ) of all trees and heights of some trees. These data indicate that in 1949 it was a forest stand of high volume $\left(1291 \mathrm{~m}^{3} / \mathrm{ha}\right)$, with dominant spruce (48.4\%). Share of other species were: fir $-30.4 \%$, beech $-19.2 \%$ and sycamore maple $-2 \%$. Similar data characterised compartment 201a, which result from description in measurement documentation in 1949.

Such a large volume in 1949 indicates that an optimal growth stadium of forest development lasted in reserve, which in the forest with beech's, spruce's and fir's share is characterised with a large volume. For instance, in Dobroč (Slovakia) volume was $1366 \mathrm{~m}^{3} / \mathrm{ha}$ (Korpel 1989), and in reserve Peručica (Bośnia) $1353 \mathrm{~m}^{3} /$ ha (Pintarič 1978).

In 60 years, significant reduction of volume occurred (Table 7). It was connected with forest stand disintegration, characteristic process for natural forest, which is a transition from optimal growth stadium to forest stand's disintegration stadium (Korpel 1989). In the years between 1960 and 1980 in Oszast, this process was accompanied by fir dieback. Also species composition changed. Despite spruce's volume decrease, the volume share of this species increased at the expense of beech's and fir's share (Table 7). This was a result of even greater decrease of fir's and beech's volume (Table 7).

High volume of examined forest before 60 years was not an exception in stands of Beskid Żywiecki and Śląski Mts. In fir forests near Rakowiec (currently Ujsoły Forest District) in 1932, forest stands of volume $1200 \mathrm{~m}^{3} / \mathrm{ha}$ occurred (Kawecki 1939). Research by Rieger (1968) shows that spruce monocultures, formed after 1840 , reached also a high volume: from 815 to $1042 \mathrm{~m}^{3} / \mathrm{ha}$.

Data presented above show that multispecies lower montane forest zone forest stands in Beskid Żywiecki Mts. were almost equal, in terms of volume, to spruce's monocultures volume, and often even exceeded them.

On favourable growth conditions for spruce on the area of Beskid Żywiecki and Ślądki Mts. affect precipitation more than $200-300 \mathrm{~mm}$ and longer period of thicker snow retention than in mountain ranges located further to east (Hess 1965; Chomicz 1977; Sikorska 1998; Twaróg 1999), and also a type of geological substratum (Rieger 1968). These are optimal conditions for spruce (Myczkowski 1977). Spruce monocultures do not support however dispersion and reduction of silvicultural risk (Bernadzki 1994). Spruce maintenance in Beskid's lower montane forest zone forests is possible and unthreatened only in multispecies forest stands.
In the years 1999 and 2009 in the Oszast reserve spruce did not show any symptoms of dieback (Tables 3 and 4). Meanwhile, this process lasted in spruce monocultures of Beskid Żywiecki and Śląski Mts. and had a mass character (Szabla 2009; Bruchwald i Dmyterko 2010).

Stages and phases of forest development in reserve indicate their complex and stable structure (Table 1).

In the years 1999-2009, on research plots in multispecies forest stand of Oszast reserve, two firs and 10 spruces died (Table 3), whereas spruce's loss was a result of tree breakage and uprooting. The two dead spruces reached 60 and $75.5 \mathrm{~cm}$ of $\mathrm{dbh}$ and did not show disease symptoms (i.e., honey fungus, bark beetles) characteristic for dead spruces from dying spruce monocultures (Żółciak et al. 2009).

In spruce monocultures of Beskid Żywiecki and Śląski Mts., crucial factors of spruce monocultures dieback, which took place beginning in 2006, were mainly: industrial emissions, weather anomalies in summer of 2006 (high temperature and drought), widespread presence of honey fungus epiphytotics, and finally periodically increasing population number of folivores and cambiophagous (Barszcz et al. 2009; Szabla 2009; Bruchwald and Dmyterko 2010). The primary cause of spruce's stands dieback was however introduction of spruce monocultures in places of multispecies forest composed of fir, beech and spruce. The causes of spruce's forest stands dieback in Beskid Mts. were presented comprehensively by Bruchwald and Dmyterko (2010) in the form of a descriptive model.

Reduced fir's share on examined plots in the years 1949-2009 was connected with the dieback process mentioned earlier (1960-1980), discussed in numerous publications (i.e., Leibundgut 1974; Roether 1979; Schütt 1981; Bernadzki 1983; Fabijanowski 1986; Keller and Imhof 1987).

A place of dead firs took over well-regenerating beech. Dynamic entering of beech may also be connected with climate warming, which causes changes in Europe forests and favours this species development (Thomasius 1991; Felbermeier 1994; Fabian and Menzel 1998). A significant increase of beech's share in regeneration was also observed in Slovak Rydawy (Saniga 1999a, 1999b) and in Dynarski Alps (Diaci et al. 2005).

Beech's volume share increase and fir's share decrease in lower subalpine multispecies forests of central Europe were described in the papers of Paulenka et al. (1996), Spiecker et al. (1996a, 1996b) and Saniga (1999a, 1999b). 


\section{Conclusions}

In multispecies lower montane forest zone forest stands, spruce not only does not show any symptoms of dieback, but even increases its volume share at the cost of fir, and so is a permanent component of forest in Beskid Żywiecki Mts. Few natural seedlings and spruce's underwood grow in terms of strong competition from dominating beech regeneration. Therefore, spruce does not reach the phase of overgrown (older) underwood. Beech during this period maintained its share defined on the basis of volume. In the years 1999 2009 , its share defined on the basis of tree number also increased. Beech's share increase in forest and its domination in regeneration allow assuming that in Oszast reserve it will be a dominant species.

Obtaining of desired share of fir and spruce species in managed forests with species composition similar to Oszast reserve requires the use of Swiss irregular shelterwood method and selection system, and also tending of natural or artificial regeneration. After execution of group cutting, fir and spruce should be introduced in forms of groups and clusters under the cover of mature beech stands. These species should also be promoted in patches of beech regeneration, with admixture of fir and spruce.

Research conducted on the area of reserve indicates that, abandonment of rational forest management that, promotes species diversity in forest of lower montane forest zone on the area of Beskid Żywiecki and Śląski Mts. will cause formation of beech monocultures or forest with beech domination in all places where the species already is present or will be introduced.

The current state, i.e., durability, structure and volume of forest in the Oszast reserve, and from a historical perspective, species composition can also be used in planning of spruce monocultures conversion in lower montane forest zone of Beskid Żywiecki and Śląski Mts. Forest stand should be created with beech, fir and spruce with a share of appropriately $20 \%, 30 \%$ and $40 \%$, plus about $10 \%$ of admixture of sycamore maple, and other valuable deciduous trees. Lower montane forest zone primeval forests of this area showed similar species composition.

\section{Acknowledgements}

Research was financed by the Faculty of Forestry, University of Agriculture in Cracow. The authors would like to warmly thank the employees of Ujsoly Forest District for assistance received.

\section{References}

Barszcz J., Małek S., Majsterkiewicz K. 2009. Dynamika zmian zagrożenia rozpadem świerczyn Beskidu Śląskiego i Żywieckiego [Changes in dynamics of decay threat of spruce stands in Silesian and Zywiec Beskid Mountains]. in: Problem zamierania drzewostanów świerkowych w Beskidzie Śląskim i Żywieckim. PAU. Prace Komisji Nauk Rolniczych, Leśnych i Weterynaryjnych 11: 93-113.

Bernadzki E. 1983. Zamieranie jodły w granicach naturalnego zasięgu. in: Jodła pospolita Abies alba Mill. Białobok S. (ed.). Warszawa - Poznań, PWN: 483-501.

Bernadzki E. 1994. Półnaturalna hodowla lasu jest nadal aktualna. Las Polski, 4: 7-10.

Bruchwald A., Dmyterko E. 2010. Lasy Beskidu Śląskiego i Żywieckiego - zagrożenia, nadzieje. Sękocin Stary, IBL, p. 77. ISBN 978-83-87647-95-7.

Chomicz K. 1977. Materiały do poznania agroklimatu Polski. Warszawa, PWN, p. 296.

Czuraj M. 1991. Tablice miąższości kłód odziomkowych i drzew stojących. Warszawa, PWRiL, p. 362.

Diaci J., Rozenbergar D., Boncina A. 2005. Interactions of light and regeneration in Slovenian Dinaric Alps: patterns in virgin and managed forests. In: Natural Forests in the Temperate Zone of Europe - Values and Utilisation. Commarmot B., Hamor F.D. (eds.). Conference 13-17 October 2003, Mukachevo, Ukraine. Proceedings. Swiss Federal Research Institute WSL, Birmensdorf; Carpathian Biosphere Reserve, Rakiv: 154-160.

Fabian P., Menzel A. 1998. Wie sehen die Wälder von morgen aus der Sicht eines Klimatologen. Forstwissenschaft Centralblatt 117: 339-354.

Fabijanowski J. 1986. Hodowla lasu wobec zagrożenia imisjami drzewostanów w górach [Silviculture in the presence of the treat of mountain forests by immisions]. Sylwan 130 (2/3): 53-66.

Felbermeier B. 1994. Arealveränderungen der Buche infolge von Klimaänderungen. Allgemeine Forstzeitschrift 49: 222-224.

Hess M. 1965. Piętra klimatyczne w Polskich Karpatach Zachodnich. Zeszyty Naukowe UJ. Prace geograficzne 11: 1-265.

Jaworski A., Kołodziej Z., Strząska T. 2001. Skład gatunkowy, budowa i struktura drzewostanów w rezerwacie Oszast [Species composition, setup and structure of tree stands in Oszast nature reserve]. Sylwan 145 (4): 5-32.

Kawecki W. 1939. Lasy Żywiecczyzny, ich teraźniejszość i przyszłość. PAU. Prace Rolno-Leśne 35: 1-171.

Keller W., Imhof P. 1987. Zum Einfluss der Durchforstung auf die Waldschäden. II Teil. Erste Ergebnisse von Waldschadenuntersuchungen in Plenterversuchsflächen der EAFV. Schweizerische Zeitschrift für Forstwesen 138: 293-320.

Korpel Š. 1989. Pralesy Slovenska. Bratislava, Veda, p. 329. ISBN 80-224-0031-9

Korpel Š. 1995. Die Urwälder der Westkarpaten. Stuttgart, Gustav Fischer Verlag, p. 310. ISBN 3-437-30702-9 
Leibundgut H. 1959. Über Zweck und Methodik der Struktur- und Zuwachsanalyse von Urwäldern. Schweizerische Zeitschrift für Forstwesen 110: 111-124.

Leibundgut H. 1974. Zum Problem des Tannensterbens. Schweizerische Zeitschrift für Forstwesen 127: 476-484.

Meyer P., Bücking W., Schmidt S., Schulte U., Willig J. 2004. Stand und Perspektiven der Untersuchung von Naturwald-Vergleichsfläschen. Forstarchiv 75: 167-179.

Myczkowski S. 1977. Świerczyny gór i wyżyn w Polsce, w: Świerk pospolity. Białobok S. (ed.). Warszawa - Poznań, PWN: 405-460.

Odum E.P. 1977. Podstawy ekologii. Warszawa, PWRiL, p. 520.

Otto H.J. 1995. Zielorientierter Waldbau und Schutz sukzessionaler Prozesse. Forst und Holz 50: 203-209.

Paulenka J., Konôpka B., Bucha T. 1996. Poškodenie lesov v oblasti Spiša. Zvolen, LVU, p. 128.

Pintarič K. 1978. Urwald Peručica als naturliches Forschungslaboratorium. Allgemeine Forstzeitschrift 33: 702-707.

Rieger R. 1968. Rozwój i zasobność wybranych drzewostanów świerkowych regla dolnego w Beskidach Zachodnich. Acta Agraria et Silvestria, Series Silvestris 8: 75-134.

Roether V. 1979. Immissionen - Hauptursache für die Tannenerkrankung? Allgemeine Forstzeitschrift 34: 582-583.

Řehák J. 1964. Vývoj stromů a porostních útvarů v přirozených lesích. Ochrana Přírody 19 (7): 105-113.

Saniga M. 1999a. Štruktura, produkčné pomery a regeneračne procesy dobročského pralesa. TU Zvolen, Vedecke Študie 2/A: 5-64.

Saniga M. 1999b. Štruktura, produkčné a regeneračne procesy badinskeho pralesa. Journal of Forest Science 45: 121-130.

Schütt P. 1981. Erste Ausätze zur experimentallen klärung des Tannensterbens. Schweizerische Zeitschrift für Forstwesen 132: 443-452.

Schütz J.Ph. 1990. Silviculture 1. Principes d'education des forêts. Lausanne, Presses Polytechniques Universitaires Romandes, p. 243. ISBN 2-88074-186-6.

Schütz J. Ph. 1999. Neue Waldbehandlungskonzepte in Zeiten der Mittelknappheit: Prinzipien einer biologisch rationellen und kostenbewussten Waldpflege. Schweizerische Zeitschrift für Forstwesen 150: 451-459.
Schütz J.Ph. 2004. Opportunistic methods of controlling vegetation, inspired by natural plant succession dynamics with special reference to natural outmixing tendencies in a gap regeneration. Annals of Forest Science 61: 149-156.

Sikorska E. 1998. Karpackie drzewostany świerkowe na tle warunków siedliskowych. Zeszyty Naukowe AR w Krakowie 332, Sesja Naukowa 56: 69-82.

Spiecker H., Mielikäinen K., Köhl M., Skovsgaard J.P. 1996a. Discussion. In: Growth trends in European forests. Spiecker H., Mielikäinen K., Köhl M., Skovsgaard J.P. (eds.). European Forest Institute Research Report 5, Berlin Heidelberg, Springer: 355-367.

Spiecker H., Mielikäinen K., Köhl M., Skovsgaard J.P., 1996 b. Conclusions and summary. In: Growth trends in European forests. Spiecker H., Mielikäinen K., Köhl M., Skovsgaard J.P. (eds.). European Forest Institute Research Report 5, Berlin Heidelberg, Springer: 369-372.

Szabla K. 2009. Aktualny stan drzewostanów świerkowych w Beskidach i ich geneza [The current state of Norway spruce stands in the Beskids and their Genesis]. In: Problem zamierania drzewostanów świerkowych w Beskidzie Śląskim i Żywieckim. PAU. Prace Komisji Nauk Rolniczych, Leśnych i Weterynaryjnych 11: 13-43.

Thomasius H. 1991. Mögliche Auswirkungen einer Klimaveränderung auf die Wälder in Mitteleuropa. Forstwissenschaft Centralblatt 110: 305-330.

Twaróg J. 1999. Rola gatunków drzew w lasach naturalnych polskich Karpat fliszowych. Las Polski 15/16: 4-6.

Zieliński R. 1972. Tablice statystyczne. Warszawa, PWN, p. 387.

Żółciak A., Lech P., Małecka M., Sierota Z. 2009. Opieńkowa zgnilizna korzeni a stan zdrowotny drzewostanów świerkowych w Beskidach [Armillaria root and the health condition of Norway spruce stands in the Beskids]. PAU. Prace Komisji Nauk Rolniczych, Leśnych i Weterynaryjnych 11: 61-72.

\section{Contributions}

Both authors (AJ and MP) designed the study, conceived the experiments, analysed data and wrote the manuscript. 